\title{
Alteration in the amount of DNA and protein in bacterial cells by UV light and ethyl methane sulphonate
}

\author{
Amina Arif ${ }^{*}$, Bushra Khan ${ }^{2}$, Sidra kanwal ${ }^{2}$ and Muhammad Azmat \\ Ullah Khan ${ }^{1}$ \\ 1. Faculty of Life Sciences, University of Central Punjab, Lahore-Pakistan \\ 2. Lahore College for Women University, Lahore-Pakistan \\ *Corresponding author's email: draminaarif@gmail.com \\ Citation \\ Amina Arif, Bushra Khan, Sidra kanwal and Muhammad Azmat Ullah Khan. Alteration in the amount of DNA and \\ protein in bacterial cells by UV light and ethyl methane sulphonate. Pure and Applied Biology. Vol. 5, Issue 4, \\ pp1216-1224. http://dx.doi.org/10.19045/bspab.2016.50146
}

Received: 23/07/2016 $\quad$ Revised: 05/10/2016 Accepted: 15/10/2016 Online First: 04/11/2016

\section{Abstract}

The biological importance of DNA is well known. There are some factors that result in its damage leading to the mutagenesis, carcinogenesis, and cell death. The microorganisms exposed to ultraviolet (UV) light and chemicals come up with some negative changes, including the reduction in the amount of DNA, leading to the decrease in the amount of protein being produced through translation. In this research E.coli methionine aminopeptidase gene ligated in the plasmid (pET21-MapE) was taken to observe the effects of UV light and ethyl methane sulphonate. As a result of the stress response, bacterial cell mass as well as amount of DNA and the protein was reduced in the bacterial culture containing plasmid (pET21-MapE) exposed to UV light and when treated with ethyl methane sulphonate. Furthermore, in comparison to UV light, ethyl methane sulphonate offered more reduction in the amount of DNA and protein. However, no observable changes were seen in the size of PCR amplified E.coli methionine aminopeptidase gene when exposed to the UV light or ethyl methane sulphonate. Giving the assumption that these factors have least effect on the stable DNA molecule when analysed by agarose gel electrophoresis but they predominantly affect the cellular machinery involved in the replication, transcription and translation processes consequently decrease in cell growth accompanying macromolecules production.

Keyword: Methionine aminopeptidase gene; UV induced damage; Ethyl methane sulphonate

Introduction

Other than some viruses DNA is key genetic material of all alive organisms. DNA is command molecule as genomic substantial, and this contains all facts regarding growth and facsimile of organism. DNA damage could result in aging of entities, cancer or some further syndromes allied to gene [1].
The major threat to change in DNA in nature is UV light. Different abrasions like nucleon threads disrupt pyrimidine glycols are induced by ultraviolet radiation conduct [2]. Chemical mutagenesis also has a great impact in the field of molecular biology. Alkylating agents were the first to be discovered as mutagens one of them is 
ethylmethyl sulfonate (EMS) which has several effects on DNA because of its potency and its easy use. EMS is most commonly used as a mutagen product in plants [3]. EMS leads to mispairing alkylated $G$ pairs with $T$ instead of $C$, ultimately results in "G-C to A-T" alterations [4]. This chemical produces DNA damage which cause point mutations, insertion or deletion mutations [5]. Biological reactivity of EMS is associated to $-\mathrm{CH}_{2}$ group that can be reassigned to range of nucleophilic sites [6]. It is a carcinogenic for mammals too [7]. E.coli has solitary one round shaped chromosome (genetic material) along with circular plasmid. It has solo chromosome of about 4,600 kb, 4,300 potential coding series, and only around 1,800 known E.coli. proteins Lab canvassers have utterly sequenced its chromosomal DNA [8].

Methionine aminopeptidase belongs to the M 24 family of proteins. MAP enzyme removes some essential amino acid residues from the amino-terminal of emerging polypeptides. MAP produce by E.coli might be an only, non-glycosylated peptide sequence embrace 264 "amino acids" and consuming a "molecular mass" of $29.33 \mathrm{kDa}$ [9]. Mone et al. have investigated UVinduced deoxyribonucleic acid mutilation [10]. This mutilation roots cells to stifle in ribonucleic acid synthesis and pledge nucleotide excision repair (NER). NER and dictation are familiarly amalgamated progressions [10].

This study designates three techniques that can cast off to the progression, degradation and structural properties, succeeding UV and EMS induced DNA damage in Escherichia coli.

\section{Material and methods \\ PCR Amplification}

Methionine aminopeptidase gene in the provided plasmid (pET21-MapE) was confirmed using specific set of primers given below in Table 1. Concentrations used for PCR were $10 \mathrm{X}$ Taq buffer $(1 \mathrm{x}), \mathrm{MgCl}_{2}$ (4 mM), dNTPs (0.2 mM each), $1.5 \mu l$ of forward primer and reverse primer (20 pmol), Genomic DNA (150 ng), Taq Polymerase $(5 \mathrm{U})$ in a reaction mixture of 50 $\mu 1$. Thermal cycler conditions used for pET21-MapE were, Initial denaturation was adjusted at $94^{\circ} \mathrm{C}$ for $10 \mathrm{~min}$. pET21-MapE plasmid was amplified for 30 cycles, each cycle with 30 seconds of denaturation at $94^{\circ} \mathrm{C}, 30$ seconds for primer annealing at $52^{\circ} \mathrm{C}$ and 30 seconds for extension at $72^{\circ} \mathrm{C}$ followed by final extension at $72^{\circ} \mathrm{C}$ for 10 min. PCR product was analyzed using $1 \%$ agarose gel electrophoresis in tris acetate EDTA (TAE) buffer (Figure 1).

Table 1. Details of the primers used in this research

\begin{tabular}{|l|c|c|c|}
\hline $\begin{array}{c}\text { Primer } \\
\text { name }\end{array}$ & Primer sequence (5'-3') & Length & $\begin{array}{c}\text { Melting } \\
\text { temperature }\end{array}$ \\
\hline Map(E)-N & CATATGGCTATCTCAATCAAGACCCC & $26 \mathrm{bp}$ & 60.7 \\
\hline Map(E)-C & TTATTCGTCGTGCGAGATTATCGCC & $25 \mathrm{bp}$ & 60.6 \\
\hline
\end{tabular}




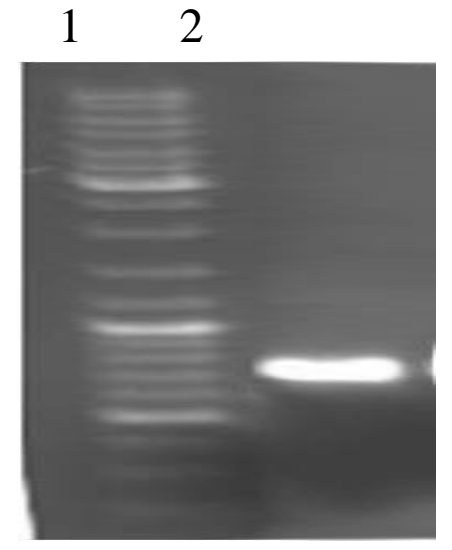

Figure 1. 1 \% agarose gel showing PCR product: Lane 1: DNA ladder, Lane 2: PCR product gene methionine aminopeptidase $795 \mathrm{bp}$

Transformation in BL 21-CodonPlus (DE3)-RIL

In $150 \mu \mathrm{L}$ of freshly prepared competent cells of BL $21,2 \mu \mathrm{L}$ of plasmid pET21MapE was added and placed in ice for 40 minutes. Heat shock was given at $42{ }^{\circ} \mathrm{C}$ for 90 seconds and again kept in ice for 5 minutes. $850 \mu \mathrm{L}$ of $\mathrm{LB}$ medium was added and incubated for 1 hour at $37^{\circ} \mathrm{C}$. Spreaded on agar plates then the plates were incubated overnight at $37^{\circ} \mathrm{C}$.

\section{UV and chemical treatment}

UV light treatment: A single bacterial colony (E.coli BL codon plus) containing plasmid pET21-MapE was inoculated into 5 $\mathrm{ml} \mathrm{LB}$ medium containing $100 \mu \mathrm{g} / \mathrm{ml}$ of ampicillin. The culture was incubated overnight in shaking incubator at $100 \mathrm{rpm}$ and $37^{\circ} \mathrm{C}$. Next day $100 \mu 1$ from this culture medium was added to 7 test tubes having 5 $\mathrm{ml} \mathrm{LB}$ medium $100 \mu \mathrm{g} / \mathrm{ml}$ ampicillin and $0.08 \mathrm{mM}$ lactose. One was considered as blank or uninduced while the remaining 6 tubes were exposed to UV light for $5 \mathrm{~min}$, $10 \mathrm{~min}, 15 \mathrm{~min}, 20 \mathrm{~min}, 25 \mathrm{~min}$ and $30 \mathrm{~min}$ respectively and then kept in shaking incubator for overnight at $37^{\circ} \mathrm{C}$. These tubes were used for plasmid isolation and expression check. Each test tube was divided in two equal parts, one half of every test tube sample was used for plasmid isolation (gel electrophoresis) and other half was used for expression check using $12 \%$ SDS PAGE.

Chemical exposure: Ethyl methyl sulphonate was used for chemical treatment with a varying concentration $0 \mu \mathrm{g} / 5 \mathrm{ml}, 5 \mu \mathrm{g} / 5 \mathrm{ml}$, $10 \mu \mathrm{g} / 5 \mathrm{ml}$ and $15 \mu \mathrm{g} / 5 \mathrm{ml}, 20 \mu \mathrm{g} / 5 \mathrm{ml}, 25$ $\mu \mathrm{g} / 5 \mathrm{ml}$. These test tubes kept at room temperature. After treating chemically all test tubes were kept in shaking incubator for overnight at $37^{\circ} \mathrm{C}$. These tubes were used for plasmid isolation and expression check. Each test tube was divided in two equal parts, one half of every test tube sample was used for plasmid isolation (gel electrophoresis) and other half was used for expression check using 12\% SDS PAGE.

\section{Results}

The gene methionine aminopeptidase present in the provided plasmid was confirmed by PCR (Figure 1). After getting confirmation about the presence of the methionine aminopeptidase gene present in the plasmid, the next step was to expose the gene (PCR product) directly to the UV light. For that $5 \mu \mathrm{l}$ each of the PCR product was taken into 7 PCR tubes.

Plasmid DNA from the UV exposed culture was isolated from each sample and $5 \mu 1$ of each sample when run on the agarose gel, indicated that with the increase in the time 
of UV exposure the amount of the DNA was decreased (Figure 3 and 4). After exposing the bacterial culture to the UV light for different times, expression of the methionine aminopeptidase as well as decline in the amount of bacterial proteins was observed with the increase in exposure time keeping the induction concentration constant (Figure 5). Plasmid DNA from the EMS treated culture was isolated from each sample and $5 \mu 1$ of each sample was run on the agarose gel which indicated that with the increase in the amount of EMS the amount of the DNA was decreased (Figure 6 and 7). After exposing the bacterial culture to the EMS for different times, expression of the methionine aminopeptidase with the decline in the amount of bacterial proteins was observed in response to the increase in exposure time keeping the induction concentration constant (Figure 8). Overall in this research it was concluded that the amount of DNA and the protein was reduced in the bacterial culture induced to UV light and treated with EMS.

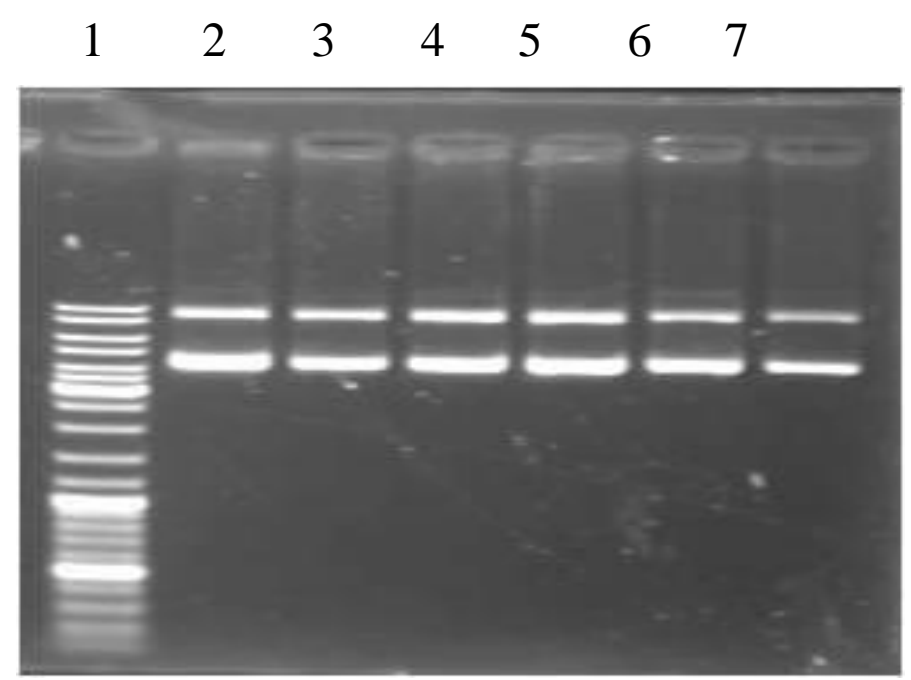

Figure 3. 1\% Agarose gel showing plasmid DNA isolated from the bacterial culture exposed to UV light. Lane 1: DNA ladder, Lane 2: Plasmid from the bacteria exposed to UV light for 5 minutes, Lane 3: Plasmid from the bacteria exposed to UV light for 10 minutes, Lane 4: Plasmid from the bacteria exposed to UV light for 15 minutes, Lane 5: Plasmid from the bacteria exposed to UV light for 20 minutes, Lane 6: Plasmid from the bacteria exposed to UV light for 25 minutes, Lane 7: Plasmid from the bacteria exposed to UV light for 30 minutes 


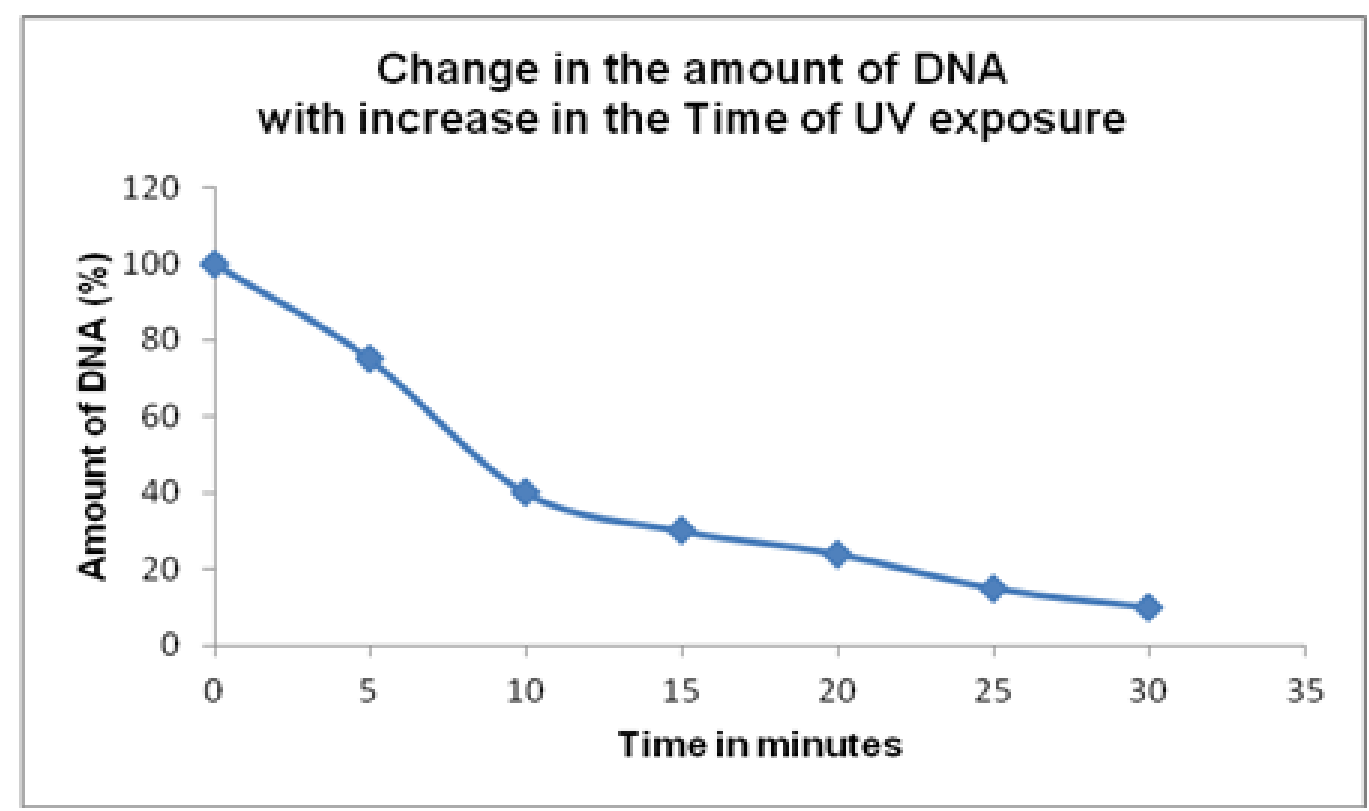

Figure 4. Change in the amount of DNA on exposure to UV light

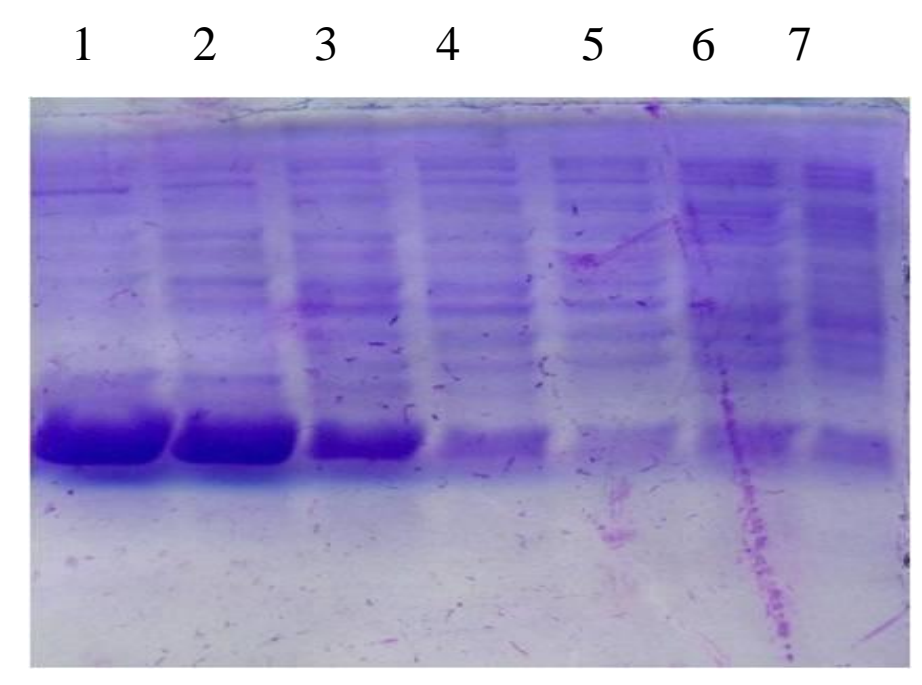

Figure 5. 12\% SDS PAGE showing expression of methionine aminopeptidase from the bacteria exposed to UV light: Lane 1: Protein from unexposed bacteria, Lane 2: Protein from bacteria exposed to UV light for 5 minutes, Lane 3: Protein from bacteria exposed to UV light for 10 minutes, Lane 4: Protein from bacteria exposed to UV light for 15 minutes, Lane 5: Protein from bacteria exposed to UV light for 20 minutes, Lane 6: Protein from bacteria exposed to UV light for 25 minutes, Lane 7: Protein from bacteria exposed to UV light for 30 minutes 


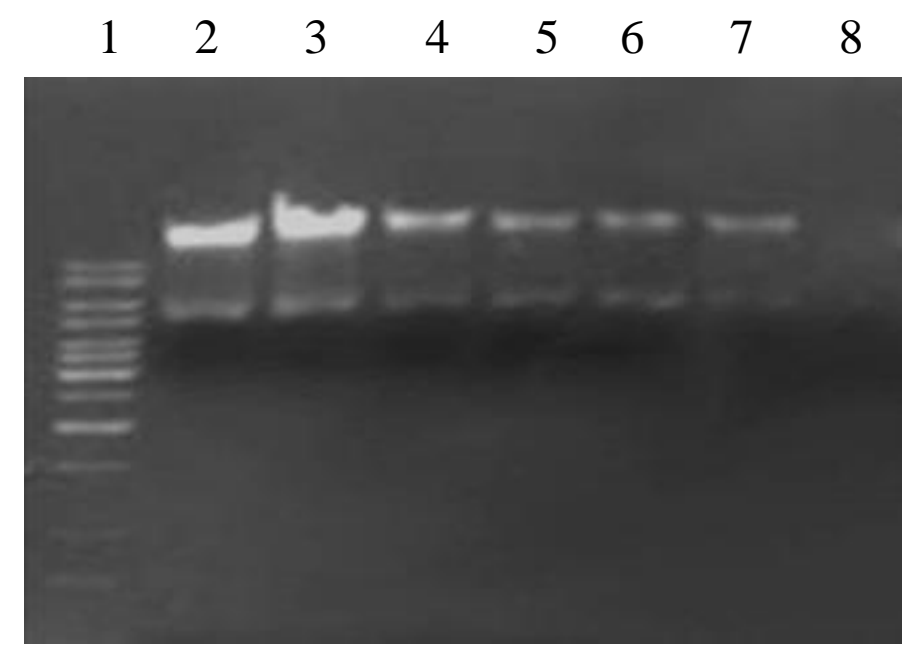

FIgure 6. $1 \%$ Agarose gel showing plasmid DNA isolated from the bacteria treated with ethyl methyl sulphonate: Lane 1: DNA ladder, Lane 2: Plasmid from the bacteria not treated with EMS, Lane 3: Plasmid from the bacteria treated with $5 \mu \mathrm{g} / \mathrm{ml} \mathrm{EMS,} \mathrm{Lane} \mathrm{4:}$ Plasmid from the bacteria treated with $10 \mu \mathrm{g} / \mathrm{ml}$ EMS, Lane 5: Plasmid from the bacteria treated with $15 \mu \mathrm{g} / \mathrm{ml}$ EMS, Lane 6: Plasmid from the bacteria treated with $20 \mu \mathrm{g} / \mathrm{ml} \mathrm{EMS,}$ Lane 7: Plasmid from the bacteria treated with $25 \mu \mathrm{g} / \mathrm{ml}$ EMS, Lane 8: Negative control

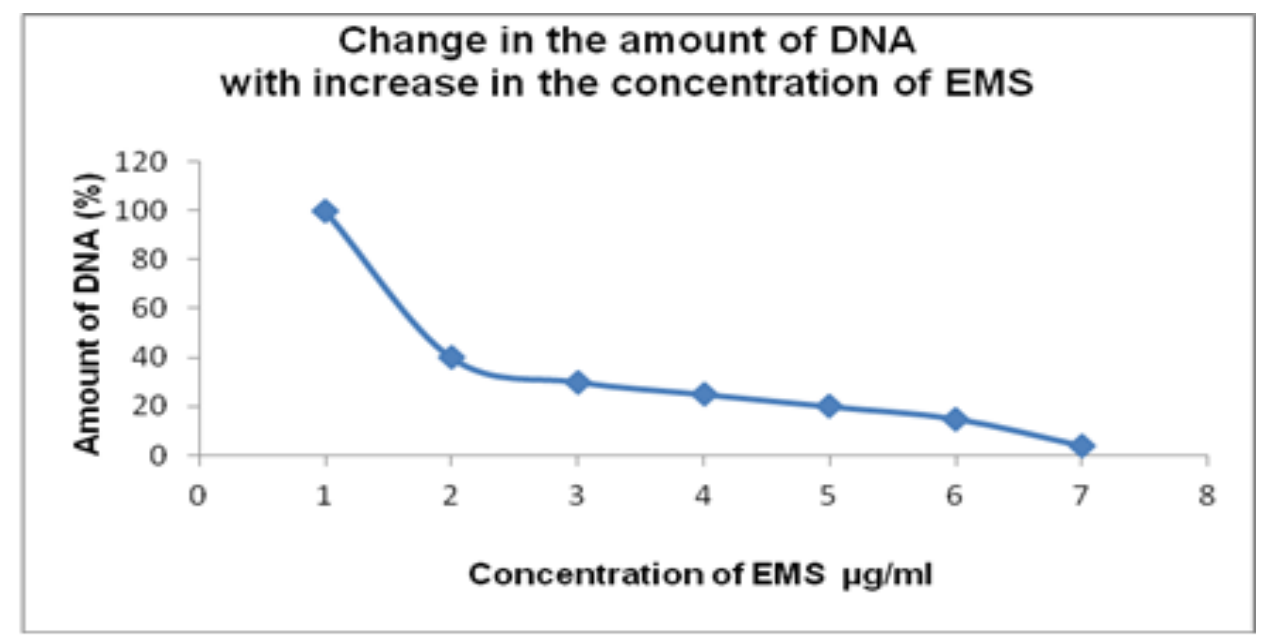

Figure 7. Change in the amount of DNA on treatment with EMS 


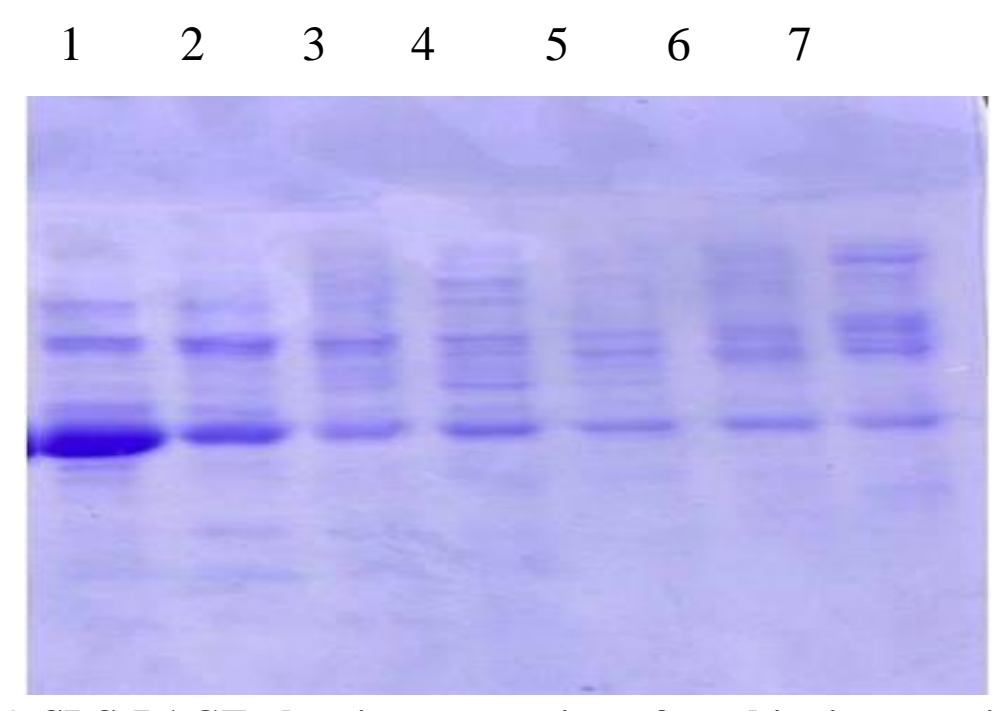

Figure 8. 12\% SDS PAGE showing expression of methionine aminopeptidase from the bacteria treated to EMS: Lane 1: Protein from the bacteria not treated with EMS, Lane 2: Protein from the bacteria treated with $5 \mu \mathrm{g} / \mathrm{ml}$ EMS, Lane 3: Protein from the bacteria treated with $10 \mu \mathrm{g} / \mathrm{ml}$ EMS, Lane 4: Protein from the bacteria treated with $15 \mu \mathrm{g} / \mathrm{ml} \mathrm{EMS}$, Lane 5: Protein from the bacteria treated with $20 \mu \mathrm{g} / \mathrm{ml} \mathrm{EMS,} \mathrm{Lane} \mathrm{6:} \mathrm{Protein} \mathrm{from} \mathrm{the}$ bacteria treated with $25 \mu \mathrm{g} / \mathrm{ml}$ EMS, Lane 7: Protein from the bacteria treated with 30 $\mu \mathrm{g} / \mathrm{ml}$ EMS

\section{Discussion}

UV energy is record risky and mutagenic factor of the solar emission continuum. Effects of UV light include the enhancement of apoptosis that is the programmed cell death. Stoppage of transcription and hindrance in the cell cycle transition that is the passage of one stage to the other to complete cell cycle [11]. DNA repair is also accounted in the after effects of the UV radiations. Here in this study UVC light $(254 \mathrm{~nm})$ was used. Undeniably, photo chemical responses are extra proficient contained by DNA at this wavelength, which near to immersion extreme of the pyrimidine and purine nucleobases [12].

DNA is a very stable molecule and it is very hard to change during vital processes. Although it is a stable molecule but stability of DNA is not absolute as there exists many factors from living organisms to environment that could cause damage. DNA damage is actually known as some abnormal changes in the structure. As molecular structure of DNA undergoes structural change during its damage which is considered as some compassionate kind of chemical indemnities. Maximum DNA mutilation can be reinstated by the restoration system in entity leaving behind very little unrepaired genetic material mutilation. However even the small unrepaired damage causes magnificent effect on the organism [13].

Bioanalytical technologies such as electrophoresis are used for the identification of the damage done by ultraviolet rays to the DNA. In this research E.coli methionine aminopeptidase gene was used as experimental DNA. After the course of UV light induction when the electrophoresis was performed there was not observable change in the amount of DNA. The mutation if any that had taken place did not appear on the agarose gel. The fragments of DNA molecule that were broken down as 
a result of stress into small pieces were small enough in size and concentration that did not appear on the agarose gel.

As the experiment was done in vitro next step was to perform the same experiment in vivo where the DNA was able to replicate using plasmid pET21-mapE. BL bacterial cells were transformed with the plasmid pET21-MapE and grown in the LB medium using ampicillin as an antibiotic. The plasmid DNA was induced to UVC light $(254 \mathrm{~nm})$ Then the transcription and translation examination were performed. Minor changes in the concentration of DNA on the Agarose gel as well as the amount of protein on SDS PAGE were observed. The reason was that UV light causes the formation of thymine cyclobutane dimmers but overall concentration remains the same. But as the duration of induction was increased the decrease in the concentration of the DNA as well as protein amount was observed as shown in the Figure 4 and 5 respectively.

Next goal was to check the amount of DNA and protein after exposing the plasmid containing bacteria to the mutagenic chemical Ethyl methanesulfonate (EMS). Nucleophilic mono and di substitution reaction mechanisms were followed by EMS in alkylation of cellular and nucleophilic sites. In this study after treating the plasmid containing bacteria to the EMS $(5 \mu \mathrm{g} / \mathrm{ml}$, $10 \mu \mathrm{g} / \mathrm{ml}, 15 \mu \mathrm{g} / \mathrm{ml}, 20 \mu \mathrm{g} / \mathrm{ml}, 25 \mu \mathrm{g} / \mathrm{ml}$ and 30 $\mu \mathrm{g} / \mathrm{ml}$,) the gradual decrease in the concentration of DNA and Protein was observed as shown in Figures 7 and 8 respectively. The same findings were reported by Xingkui Tao et al., who determined the optimal concentration of EMS mutation for E.coli cells six EMS concentration gradients $(0.1 \%, 0.2 \%, 0.3 \%$, $0.4 \%, 0.5 \%, 0.6 \%$ ). Their results showed that the survival rate of the cells was significantly different under the different concentrations of EMS. In the same processing time, the EMS concentration was increased, but the suspension cells survival rate decreased gradually [14]. Reason was that in the presence of EMS the bacterial cells come in stress therefore mRNA production decreased leading to the reduction of protein amount.

\section{Conclusion}

Overall in this research it was concluded that the amount of DNA and the protein turned out to be reduced in the bacterial culture induced to UV light and treated with EMS. However when DNA was directly induced to UV light no observable change in the amount of DNA was seen. This is because DNA is quite stable molecule and exposure to UV light (5-30 minutes) cause no effect on its amount. In comparison to UV and chemical method more reduction in the amount of DNA and protein was observed in the experiment when bacteria were treated with EMS. Where the sudden decrease in the amount of DNA was observed with only $5 \mu \mathrm{g} / \mathrm{ml}$ EMS.

\section{Authors' contributions}

Conceived and designed the experiments: A Arif, Performed the experiments: A Arif \& S Kanwal, Analyzed the data: A Arif, Contributed reagents/ materials/ analysis tools: B Khan, Wrote the paper: MAU Khan.

\section{References}

1.Heil K, Pearson D \& Carell T (2011). Chemical investigation of light induced DNA bipyrimidine damage and repair. Chem Soc Rev 40:4271-8

2.Abedi-Moghaddam N, Bulic A, Herderson L \& Lam E (2004). Survival of Escherichia coli to UV irradiation during exponential and stationary phases of growth. $J$ Exp Microbiol Immunol 5:44-9

3.Bose JL (2016), The Genetic Manipulation of Staphylococci. Methods and Protoc 1373: 111-115. 
4.Walker GC (1984). Mutagenesis and inducible responses to deoxyribonucleic acid damage in Escherichia coli. Microbiol Rev 48:60

5.Gayou O, Aniol KA, Averett T, Benmokhtar F, Bertozzi W, Bimbot L, Brash EJ, Calarco JR, Cavata C \& Chai $\mathrm{Z}$ (2002). Measurement of G E p/G M p in $\mathrm{e} \rightarrow \mathrm{p} \rightarrow \mathrm{e} \mathrm{p} \rightarrow$ to $\mathrm{Q} 2=5.6 \mathrm{GeV} 2$. Phys Rev Lett 88:092301

6.Takeda K, Kaisho T \& Akira S (2003). Toll-like receptors. Annu Rev Immunol 21: 335-76

7.Arif A, Gardner Q-T-AA, Rashid N \& Akhtar M (2015). Production of human interferon alpha-2b in Escherichia coli and removal of $\mathrm{N}$-terminal methionine utilizing archaeal methionine aminopeptidase. Biologia 70:982-7

8.Gonzalez T \& Baudouy J (1996). Bacterial aminopeptidases: properties and functions. FEMS Microbiol Rev 18: 319-44

9.Lowther WT \& Matthews BW (2000). Structure and function of the methionine aminopeptidases. $B B A$ Protein Struct M 1477: 157-67

10. Mone MJ, Volker M, Nikaido O, Mullenders LH, van Zeeland AA, Verschure PJ, Manders EM \& van
Driel R (2001). Local UV-induced DNA damage in cell nuclei results in local transcription inhibition. EMBO Rep 2: 1013-7

11. Giroux X \& MacNeill SA (2016). A novel archaeal DNA repair factor that acts with the UvrABC system to repair mitomycin C-induced DNA damage in a PCNA-dependent manner. $\mathrm{Mol}$ Microbiol 99: 1-14

12. Patel VK, Maji D, Pandey SS, Rout PK, Sundaram S \& Kalra A (2016). Algal Res 16: 36-45.

13. Daboussi F, Zaslavskiy M, Poirot L, Loperfido M, Gouble A, Guyot V, Leduc S, Galetto R, Grizot S, Oficjalska D \& Perez C (2012). Chromosomal context and epigenetic mechanisms control the efficacy of genome editing by rare-cutting designer endonucleases. Nucleic Acids Res 40: 6367-79

14. Yang X, Xiong X, Cao J, Luan B, Liu Y, Liu G \& Zhang L (2015). Matrix precipitation: a general strategy to eliminate matrix interference for pharmaceutical toxic impurities analysis. J Chromatogr A 1379: 16-23. 